\title{
Alien hand syndrome
}

Sarah Barbara Elisa Debray, MD, and Jelle Demeestere, MD

Neurology ${ }^{\circledR}$ 2018;91:527. doi:10.1212/WNL.0000000000006172

A 94-year-old patient developed the alien hand syndrome in the left (nondominant) hand following an ischemic stroke of the right parietotemporal lobe (including postcentral gyrus, superior and inferior parietal lobule) due to an occlusion of the posterior division of the right middle cerebral artery.

Video 1 illustrates involuntary limb movements of the left arm and hand that often counteract actions of the right hand. The affected limb exhibits compulsive manipulations such as grasping and fidgeting. The patient acknowledges ownership of the affected limb but experiences a sense of loss of control and frustration.

\section{Author contributions}

Sarah Debray: writing of the manuscript, clinical assessment, video acquisition, and editing. Jelle Demeestere: conceptualization of the submission, revising the manuscript for intellectual content.

\section{Acknowledgment}

The authors thank the patient and her family for their cooperation and informed consent. The authors acknowledge Wouter Leemans and Helena Cockx for their help in obtaining clinical data and video material, and David Robben for his technical assistance.

\section{Study funding}

No targeted funding reported.

\section{Disclosure}

The authors report no disclosures relevant to the manuscript. Go to Neurology.org/N for full disclosures.

\author{
Correspondence \\ Dr. Debray \\ sarah.debray@uzleuven.be
}

MORE ONLINE

- Video

From the Department of Neurology (S.B.E.D., J.D.), University Hospitals Leuven; Department of Neurosciences (J.D.), Experimental Neurology, KU Leuven-University of Leuven; and Laboratory of Neurobiology (J.D.), VIB Center for Brain \& Disease Research, Leuven, Belgium. 


\title{
Neurology
}

\author{
Alien hand syndrome \\ Sarah Barbara Elisa Debray and Jelle Demeestere \\ Neurology 2018;91;527 \\ DOI 10.1212/WNL.0000000000006172
}

This information is current as of September 10, 2018

\section{Updated Information \& Services}

Citations

Subspecialty Collections

Permissions \& Licensing

Reprints including high resolution figures, can be found at: http://n.neurology.org/content/91/11/527.full

This article has been cited by 1 HighWire-hosted articles: http://n.neurology.org/content/91/11/527.full\#\#otherarticles

This article, along with others on similar topics, appears in the following collection(s):

All Cerebrovascular disease/Stroke

http://n.neurology.org/cgi/collection/all_cerebrovascular_disease_strok e

Motor Control

http://n.neurology.org/cgi/collection/motor_control

Information about reproducing this article in parts (figures,tables) or in its entirety can be found online at:

http://www.neurology.org/about/about_the_journal\#permissions

Information about ordering reprints can be found online:

http://n.neurology.org/subscribers/advertise

Neurology ${ }^{\circledR}$ is the official journal of the American Academy of Neurology. Published continuously since 1951, it is now a weekly with 48 issues per year. Copyright (O) 2018 American Academy of Neurology. All rights reserved. Print ISSN: 0028-3878. Online ISSN: 1526-632X.

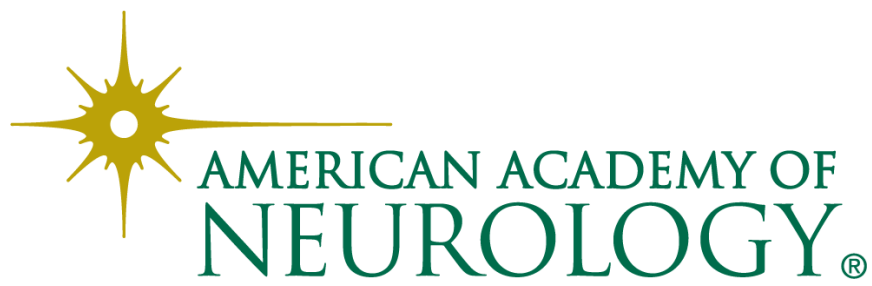

